\title{
Activities and Ergonomics of Workers in Broiler Hatcheries
}

\section{-Author(s)}

\section{Carvalho CCS'}

Souza C de F"

Tinôco I de FF"

Santos LVIII

Minette LJ"

Silva EP da

Universidade Estadual de Montes Claros

" Universidade Federal de Viçosa

III Universidade Estadual do Sudoeste da Bahia

\section{Mail Address}

Corresponding author e-mail address Cinara da Cunha Siqueira Carvalho

Rua Marcelino Nunes da Silva, 284, Ribeirão do Ouro, Janaúba, Minas Gerais, 39440-000, Brazil

Phone: (38) 91281796

E-mail: cinarasiqueira@yahoo.com.br

\section{-Keywords}

Broiler chicken production, ergonomics, egg hatching, workplace safety.

\section{ABSTRACT}

The objective this study was to assess ergonomic factors, posture and biomechanics of workers of a broiler egg hatchery. The analysis of ergonomic factors was based on physical work load, thermal environment, and exposure to light and noise. The posture of workers was analyzed using photographic records which were evaluated by the software program OWAS (Ovako Working Posture Analysing System). A biomechanics analysis was also performed based on the photographs taken of the employee at various angles, which were used as inputs to the Michigan two-dimensional biomechanical model software program. The results show that certain activities can be considered unhealthy due to the exposure of employees to physical and thermal overload. The continuous noise levels and lighting were outside the range considered adequate by the regulations of the Brazilian Ministry of Labor. The manner in which certain activities are carried out when associated with weight and poor posture can result in body lesions in broiler hatchery employees. It is therefore necessary to apply specific ergonomic programs, including scheduled breaks, training, and other measures in order to reduce or to eliminate the risks involved in these activities.

\section{INTRODUCTION}

In the last decades, the Brazilian poultry industry has expanded internationally and can now be considered an industrial complex that should not be analyzed not only from the production perspective, but also through a systemic approach considering technology developments, production efficiency, and diversification of consumption (Tinôco et al., 2004; Menegali et al., 2010).

The concern of the poultry industry to maintain high productivity levels while complying with the rigorous standards of the domestic and international markets relative to environmental sustainability and animal and human welfare has fostered the emergence and the adoption of technical standards that regulate the entire poultry production process. In the context of production, the egg incubation process stands out as a potential source of infection for birds and workers due to the large numbers of undesirable microorganisms present in the environment and to the tasks that result in unhealthy working conditions (Tinôco, 2001; Tessari et al., 2002; Menegali et al., 2010).

In this sense, issues related to the ergonomics of workers of the broiler industry can be improved and thus provide welfare to those employees.

Poor postures (twisting of the spine sometimes associated with carrying heavy loads) while performing specific tasks can often speed up musculoskeletal wear. The study of the relationship between 
posture and anatomical structures affected by various pathogens is a growing concern in many fields of science, out of which biomechanics is highlighted (Sacco et al., 2003).

Biomechanics, the science that studies the movement of the human body and its postures according to the laws of mechanics, anatomy, and physiology, can aid in the mechanical interpretation of postures adopted as a function of the chronic use of any implement, of repetitive actions and of inadequate postures (lida, 2005; Sacco et al., 2003; Couto, 1996).

In this context, the objective of this study was to evaluate the ergonomic factors that affect the employees working in a broiler hatchery and to analyze the effect of different postures on their health, based on postural and biomechanical analysis. Based on the results, recommendation are made to provide better working conditions, according to the Regulatory Standards of the Brazilian Ministry of Labor and Employment.

\section{MATERIAL AND METHODS}

This study was conducted at a commercial hatchery, during the work shift that begins at 07:30h and ends at 20:00h. The study obtained full consent and authorization of the company's board, management, and employees.

The ergonomic factors of 48 workers (90\% of the hatchery's employees) were evaluated, out of which 36 were women and 12 were men, who were classified by age, height, and weight.

The following tasks were analyzed: the arrival of the eggs at the hatchery, egg grading, incubation, egg turning, and chick sexing, vaccination and loading onto transporting trucks.

Physical workload was analyzed using a heart rate monitor (model S610i, Polar Electro, Kempele, Finland), consisting of a digital receiver, an elastic band and a sensor transmitter placed at the height of the chest. This device was placed on the workers at the beginning of the shift (07:00h) and removed at the end of the shift (17:00h), and was carried during the entire shift, including hygiene, lunch and rest breaks. The heart rate monitor was also used by the employees responsible for cleaning the crates and loading them onto the truck from 17:00h to 20:00h.

Based on the collected data, the physical workload of each task and the cardiovascular workload while performing the tasks were determined. Cardiovascular load was calculated according to the following equation:
$C V L=[(H R W-H R R) /(M H R-H R R)] \times 100$

Where:

$\mathrm{CVL}=$ cardiovascular load, in \%;

HRW = heart rate at work, in bpm;

$\mathrm{HRR}=$ heart rate at rest, in bpm;

$\mathrm{MHR}=$ maximum heart rate, $(220-$ age $)$.

Physical workload was classified according to heart rate while at work (Table 1), as proposed by Couto (1996).

Table 1 - Classification of the workload based on the heart rate when working.

\begin{tabular}{ll}
\hline Physical workload & Heart rate in bpm \\
\hline Very light & $<75$ \\
\hline Light & $75-100$ \\
\hline Moderately heavy & $100-125$ \\
\hline Heavy & $125-150$ \\
\hline Very heavy & $150-175$ \\
\hline Extremely heavy & $>175$ \\
\hline
\end{tabular}

Source: Couto, 1996.

The WBGT index (wet-bulb glove temperature) was used to evaluate thermal comfort and its correlation with the performance of a particular task. Workers' tolerance to heat exposure was determined according to the Brazilian Legislation on Unhealthy Activities and Operations NR 15 (2004). WBGT data were collected using a WBCT digital thermometer (Wibget, model RSS-214, Ontario, Canada). The device was placed in the geometric center of each room at a height corresponding to average workers' thorax height and programmed to record dry bulb, wet bulb, and black globe temperatures. Data was downloaded and stored on a computer for later analysis.

The WBGT index was calculated using the equation described below for indoor evaluation (no solar load), according to NR 15 (2004):

WBGT $=0.7 \mathrm{nbt}+0.3 \mathrm{gt}$

Where:

nbt $=$ natural wet bulb temperature, ${ }^{\circ} \mathrm{C}$

gt $=$ globe temperature, ${ }^{\circ} \mathrm{C}$

Using the metabolism rates per type of activity shown in Table 2, type of activity was correlated with the WBGT index (Table 3 ) in order to determine the adoption or not of scheduled breaks due to thermal overload at the site. 
Table 2 - Metabolism rates per activity type.

\begin{tabular}{|c|c|c|c|}
\hline \multicolumn{3}{|l|}{ Type of Activity } & $\mathrm{kcal} / \mathrm{h}$ \\
\hline \multicolumn{3}{|l|}{ Seated at rest } & 100 \\
\hline \multicolumn{4}{|l|}{ Light Work } \\
\hline \multicolumn{3}{|c|}{$\begin{array}{l}\text { Seated, moderate movements with the arms and torso } \\
\text { (ex: typing) }\end{array}$} & 125 \\
\hline \multicolumn{3}{|c|}{$\begin{array}{l}\text { Seated, moderate movements with the arms and legs } \\
\text { (ex: driving) }\end{array}$} & 150 \\
\hline \multicolumn{3}{|c|}{$\begin{array}{l}\text { Standing, light work using machines or at a bench, using } \\
\text { mainly the arms }\end{array}$} & 150 \\
\hline \multicolumn{4}{|c|}{ Moderate Work } \\
\hline \multicolumn{3}{|c|}{ Seated, vigorous movements with the arms and legs } & 180 \\
\hline \multicolumn{3}{|c|}{$\begin{array}{l}\text { Standing, light work with machines or at a bench, with } \\
\text { some movement }\end{array}$} & 175 \\
\hline \multicolumn{3}{|c|}{$\begin{array}{l}\text { Standing, moderate work with machines or at a bench, } \\
\text { with some movement }\end{array}$} & 220 \\
\hline \multicolumn{3}{|c|}{ In movement, moderate work of lifting or pushing } & 300 \\
\hline \multicolumn{4}{|c|}{ Heavy work } \\
\hline \multicolumn{3}{|c|}{$\begin{array}{l}\text { Intermediate work of lifting, pushing or dragging } \\
\text { weights }\end{array}$} & 440 \\
\hline \multicolumn{3}{|l|}{ Fatiguing work } & 550 \\
\hline \multicolumn{4}{|l|}{ Source: NR 15 (2004). } \\
\hline \multicolumn{4}{|c|}{$\begin{array}{l}\text { Table } 3 \text { - Tolerance limits for intermittent working witl } \\
\text { rest periods at the workplace in WBGT }\left({ }^{\circ} \mathrm{C}\right) .\end{array}$} \\
\hline \multicolumn{4}{|c|}{ Working TYPE OF ACTIVITY } \\
\hline $\begin{array}{l}\text { arrangements with } \\
\text { intermittent rest in the } \\
\text { workplace (per hour) }\end{array}$ & LIGHT & MODERATE & HEAVY \\
\hline Continuous work & up to 30.0 & up to 26.7 & up to 25.0 \\
\hline $\begin{array}{l}45 \text { minutes of work } \\
15 \text { minutes of rest }\end{array}$ & 30.1 to 30.6 & 26.8 to 28.0 & 25.1 to 25.9 \\
\hline $\begin{array}{l}30 \text { minutes of work } \\
30 \text { minutes of rest }\end{array}$ & 30.7 to 31.4 & 28.1 to 29.4 & 26.0 to 27.9 \\
\hline $\begin{array}{l}15 \text { minutes of work } \\
45 \text { minutes of rest }\end{array}$ & 31.5 to 32.2 & 29.5 to 31.1 & 28.0 to 30.0 \\
\hline $\begin{array}{l}\text { Working is not } \\
\text { allowed without } \\
\text { adoption of adequate } \\
\text { control measures }\end{array}$ & $\begin{array}{l}\text { greater than } \\
32.2\end{array}$ & $\begin{array}{l}\text { greater than } \\
\quad 31.1\end{array}$ & $\begin{array}{l}\text { greater than } \\
\quad 30.0\end{array}$ \\
\hline
\end{tabular}

Source: NR 15 (2004).

Noise levels in the workplace were determined using a sound pressure level meter (SPL, model DOS 500, Instrutherm Measuring Instruments, São Paulo, Brazil) with an accuracy of $\pm 1 \mathrm{~dB}$ and resolution of $0.1 \mathrm{~dB}$ operating on the compensation scale " $A$ " (Slow), according to a 30-130 scale. Measurements were obtained every 30 minutes in order to detect noise variations during the shift. When determining the continuous noise level equivalent (Leq), a certain period the sound energy was considered as equal to the total sound energy of a succession of discrete noises during the same period (NHO 01, 2001). For the purposes of this standard, Leq is calculated by the following equation:

$$
\mathrm{L}_{\mathrm{q}}=\mathbb{0} \log \left[\frac{1}{\mathrm{n}} \sum_{\mathrm{i}=1}^{\mathrm{n}} \text { fi.0 }{ }^{0,1 . \mathrm{Li}}\right]
$$

Where:

Leq $=$ continuous equivalent noise level, in $\mathrm{dB}(\mathrm{A})$

$\mathrm{n}=$ number of valid measurements

$\mathrm{fi}=$ Li noise frequency

$\mathrm{Li}=$ instantaneous noise level measured every $10 \mathrm{~s}$, in $d B(A)$.

Noise levels recorded at the hatchery were analyzed and compared with the values established by NR 15 (2004) of the Brazilian legislation.

Lighting evaluation was based on the identification and characterization of the lighting design within each sector of the hatchery. Light in the workplaces was measured using a digital light meter (model LDR380, Instrutherm Measuring Instruments Ltda, São Paulo, Brazil) with an accuracy of $\pm 5 \%$ (5 digits) and a resolution of 0.01 lux. Readings (in lux) were made by positioning the base of the photocell on a horizontal plane at the workers' height. Data were collected every 30 minutes and the identified illumination values were compared with the values established by the NBR 5413 in 1992.

Postures adopted by employees during working hours were evaluated by the OWAS method (Ovako Working Posture Analyzing System). Postures were analyzed based on the photographic records of the individual in a real work situation. Postures related to the torso, arms, legs were considered, as well as the use of force to perform a function or activity to estimate the proportion of time during which forces are exerted and postures assumed.

During the observation period postures related to the parts of the body were considered, assigning values to each posture using with a six-digit code. The first digit of the code indicates the position of the back; the second, the position of the arms; the third, the position of the legs; the fourth digit indicates the load or use of force, and the fifth and sixth digits, the phase of work (Wilson \& Corlett, 1995).

\section{$1^{\text {st }}$ Digit - Back}

1 - Erect, 2 - Inclined forward or backwards, 3 Twisted or inclined to the sides, 4 - Inclined and twisted or inclined to the front and the sides

\section{$2^{\text {nd }}$ Digit - Arms}

1 - Both arms below the level of the shoulders, 2 - One arm at the level of the shoulders or below it, 3 - Both arms at the level of the shoulders or above it. 


\section{Activities and Ergonomics of Workers in Broiler Hatcheries}

\section{$3^{\text {rd }}$ Digit - Legs}

1 - Seated, 2 -Standing with both legs straightened, 3 - Standing with the body weight on one of the straightened legs, 4 - Standing or squatting with both knees bent, 5 - Standing or squatting with one knee bent, 6 - kneeling on one or both knees, 7 - Walking or moving.

\section{$4^{\text {th }}$ Digit - Lifting or use of force}

1 - Weight or force required are $10 \mathrm{~kg}$ or less, 2 weight or force required exceeds $10 \mathrm{~kg}$, but less than $20 \mathrm{~kg}, 3$ - weight or force needed exceeds $20 \mathrm{~kg}$.

$5^{\text {th }}$ and $6^{\text {th }}$ Digits - Phase of work

The two digits are reserved for phase activity ranging from 00 to 99, selected based on subdivision of tasks.

The combination of the positions of the back, arms, legs and the use of force in the OWAS method received a score that was included in the analysis system Win OWAS, with which it was possible to categorize levels of action for corrective measures.

The method thus classified posture into four categories:

1: normal posture not requiring special care.

2: posture should be checked during the next work routine.

3: posture that deserves short-term attention.

4: posture that deserves immediate attention.

Biomechanical evaluation was based on photographic records of the workers at various angles while performing their activities. The loads involved were measured and used as inputs to the computer program of the two-dimensional biomechanical model for predicting the postures adopted when performing activities as well as the static forces required, developed by the University of Michigan, United States. The twodimensional biomechanical program evaluates the risk of injury to the shoulder, elbow, back, hip, knee, and ankle. The results obtained with this software allow establishing a recommended load limit, which corresponds to the weight that over $99 \%$ of men and $75 \%$ of women are able to lift.

\section{RESULTS AND DISCUSSION}

Using the data collected by the heart rate monitor and analyzed according to equation 2, physical workload at the hatchery ranged from light to moderately heavy. It was verified that all activities are performed in a standing position with no place for seating. Therefore, according to Fiedler \& Venturoli (2002), it is of utmost importance to encourage voluntary adoption of breaks for muscle rest and relaxation, especially when activities require constant standing.
Activities such as egg grading, hatching, and turning, chick sexing and vaccination, removal of the eggshells, and inspection of the incubator, although carried out almost exclusively by women, require little physical force. Additionally, the company adopts a system for rotation of activities to allow for variations in posture and movements, seeking to improve biomechanical aspects (Silva et al., 2010).

Activities including the loading of egg crates that arrive to be incubated, cleaning the plastic crates arriving from egg grading, hatching and sexing (which crates are made of metal in the two latter stages), as well as loading of the crates with chicks that are dispatched to the farms, are considered light to moderately heavy and, therefore, are performed only by men.

The association of incubation + turning activities were classified as light to moderately heavy, due to overload imposed on the physical condition of the employees. Even when performing these activities, an increase heart rate when at work was observed in the hatchery (121 bpm), with CVL of $30 \%$. This is probably due to the force required to remove the carts with egg trays from the incubator and to push them to the egg-turning room. Furthermore, this situation was reported by the employees as the most tiring activity in the hatchery. A heart rate at work of $118 \mathrm{bpm}$, with a CVL of $32 \%$, was obtained when workers loaded the crates of chicks onto the truck. These values are related to the fact that the employee has to push, lift, and carry several crates at the same time for a period of 40 minutes. According to Couto (1996), during a workday of 8 hours, heart rate should not exceed 110 bpm. Adverse conditions may increase the demand on the cardiac and respiratory systems, thereby compromising workers' health. Therefore, the tasks of moving the incubator carts and chick-crate loading require the establishment of rest pauses.

Workers that load the chick-transport truck are also responsible for cleaning the metal incubator trays. During the performance of this activity, employees wash the trays using large amounts of water. Despite wearing protective boots and plastic garments, workers get wet, which may expose them to the risk of catching a cold. Furthermore, coping with the strong water pressure of the hose, loading metal crates, and pushing carts increased heart rate to 109 bpm, which is close to the value established by Couto (1996) for recommending breaks.

The CCV values obtained for the remaining activities do not demonstrated any need of concern with workers' health. 
Carvalho CCS, Souza C de F, Tinôco I de FF, Santos LV, Minette U, Silva EP da

Activities evaluated by the WBGT index ranged between moderate and heavy, according to specifications of the NR 15 (2004) of the Ministry of Labor and Employment.

In the transfer area, which include the incubation and the egg-turning rooms, the employees enter inside the incubation chamber several times per shift to remove the carts and thereby are exposed to a thermal overload at $37.5^{\circ} \mathrm{C}$, whereas in the waiting room of the incubation and egg-turning room, WBGT is around $30^{\circ} \mathrm{C}$. Considering that the activity was classified as moderate, the maximum WBGT for this condition should not exceed $26.7^{\circ} \mathrm{C}$. Both in the transfer and the turning rooms, the employees are exposed to thermal overload for a period of 2 hours.

Relative to the thermal comfort zone, according to NR 17 (2004), a worker on an 8-hour work shift may be exposed to temperatures ranging from 20 to $23^{\circ} \mathrm{C}$ and relative air humidity of not less than $40 \%$. According to Grandjean (1998), excessive heat in the workplace results in fatigue and sleepiness, which reduces prompt response and increases the tendency of failure. Marcon (2004) evaluated the thermal comfort in the broiler hatchery chick sexing. The WBGT index ranged from $21^{\circ} \mathrm{C}$ in the morning to $24^{\circ} \mathrm{C}$ at the time of greatest sunlight (inside the room). However, when the index reached $24^{\circ} \mathrm{C}$, the fan was automatically actioned by the control panel.

The evaluated average noise level complied with the standards set by the NR 15 (2004), which recommends maximum exposure of $85 \mathrm{~dB}(\mathrm{~A})$ for 8 hours of work. Noise level values obtained in the egg-grading room and in the external area were below that established by NR 15 (2004), possibly due to the absence of noisegenerating machinery at these locations. However, inside the incubation and transfer rooms, the noise level was above the recommended standard. The main sources of noise were the incubators and egg-turning machines.

During sexing, the noise level was $83 \mathrm{~dB}(\mathrm{~A})$. However, vaccination was performed during this stage also. When the vaccination machines completed the score of 100 chicks vaccinated, a loud beep was emitted to warn the employees to begin to fill another crate with birds. At time the beep was emitted (for 2 seconds), the noise generated by the vaccination machine was $101 \mathrm{~dB}(\mathrm{~A})$, and the noise reached $88 \mathrm{~dB}$ $(A)$ in the area chicks were being sexed.

According to Marcon (2004), the noise generated by a beep triggered at the end of the operation of a machine may be useful to the operator, but it can be
Activities and Ergonomics of Workers in Broiler Hatcheries

considered a noise nuisance by the co-workers, who may be concentrated in another task. According to that author, noise should be evaluated in the workplace. Reducing noise may be challenging, starting with machinery design and with use of appropriate personal protective equipment (PPE).

However, it was observed that workers did not use hearing protection. According to Carvalho et al. (2008), the employee must be aware of the importance of hearing protection, because long exposure times cause hearing losses. If the workers are not aware that hearing protective devices need to be used continuously and daily, their hearing may be severely impaired, resulting in high labor costs.

Sexing and vaccination were performed together in a single large room. Therefore, due to the noise generated by the vaccination machines and chicks, sound levels constantly varied.

According to the lighting values recommended in NBR 5413 (1992), lighting level was above the standard only in the outdoor area, which was lighted by natural light. In the other sites studied, the lighting was below the optimal values. Lighting in these areas were low probably due to insufficient number of lamps. However, it was observed that the performance of the operations of unloading egg cartons, egg grading, egg transfer, and chick vaccination were not impaired.

Chicks are sexed by looking at the length of the feathers in the tip of the wing, and therefore, adequate lighting is required. Performing this task under low lighting causes eyestrain and sexing errors. Insufficient lighting also affects loading of chick crates into truck and inspecting inside the incubators. Loading chick crates require careful attention, as crates are separated by sex and farm of destination. The inspection inside the incubator is performed with the aid of manual lamps that are switched on only when necessary.

Work performed under insufficient lighting causes eyestrain problems. According to lida (2005), visual fatigue is characterized by eye irritation and tearing. Blinking frequency increases and the vision becomes blurred and double, reducing visual accuracy. In more advanced stages, it causes headaches and nausea and may lead to depression and emotional irritability, decreasing productivity and work efficiency.

All body postures assumed by the hatchery workers were analyzed and classified by the computer program OWAS for postural assessment. Table 4 presents the photographic record of the postures adopted while performing a given task, the combination of postures, and the category in which these positions are classified. 
Table 4 - Photographic record of postures, classified according to the OWAS system considering the different activities performed in the broiler hatchery

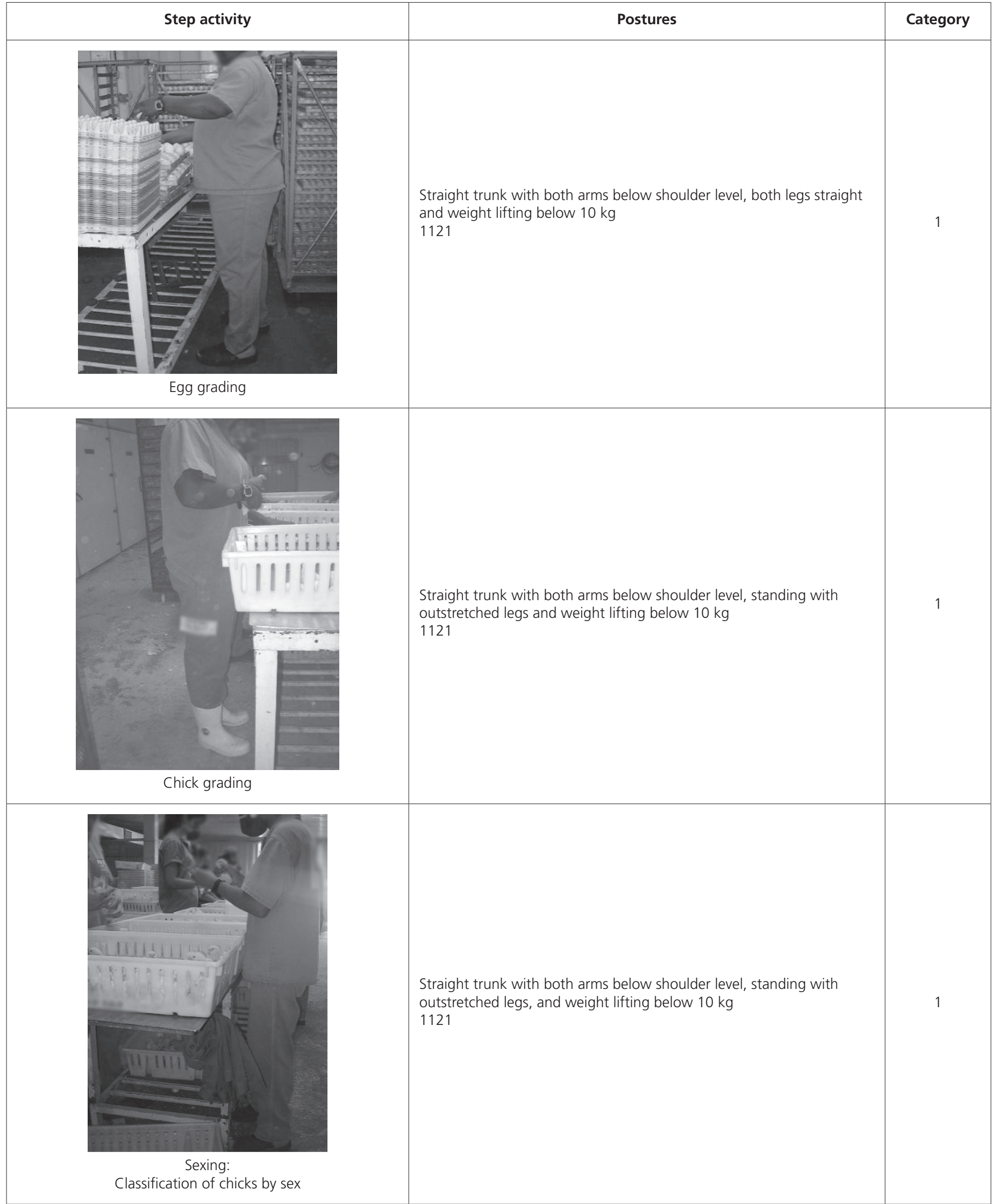




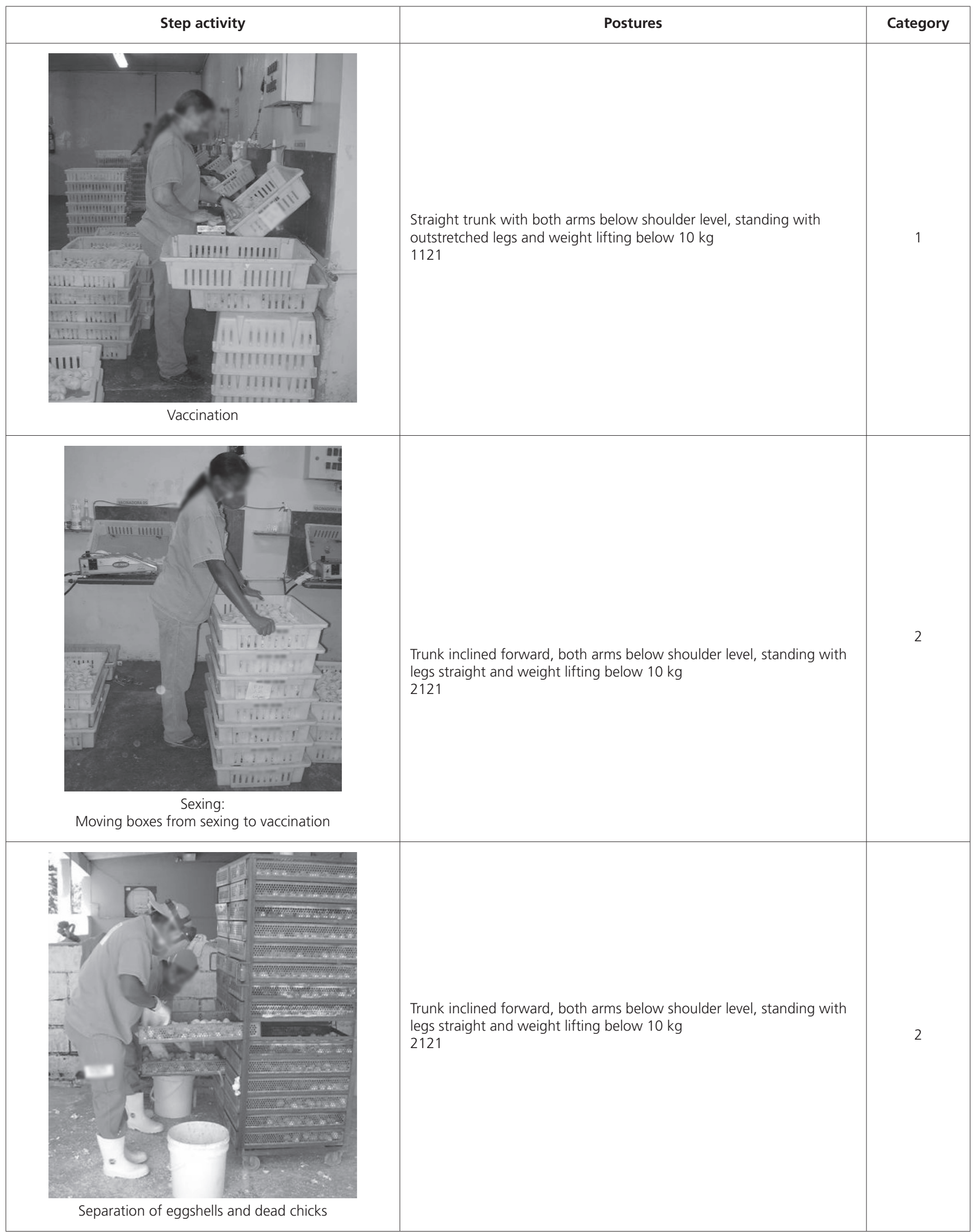


Hatcheries

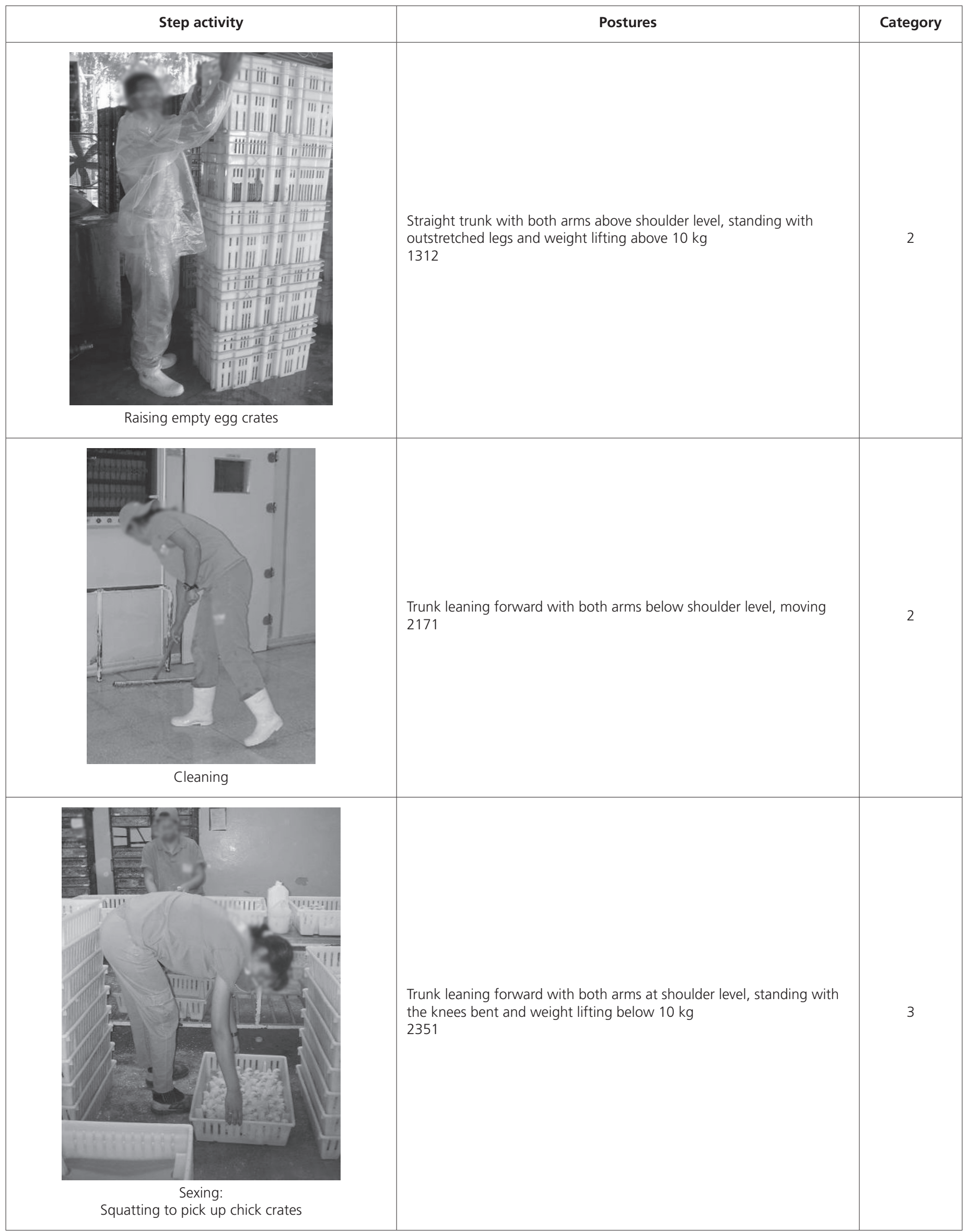




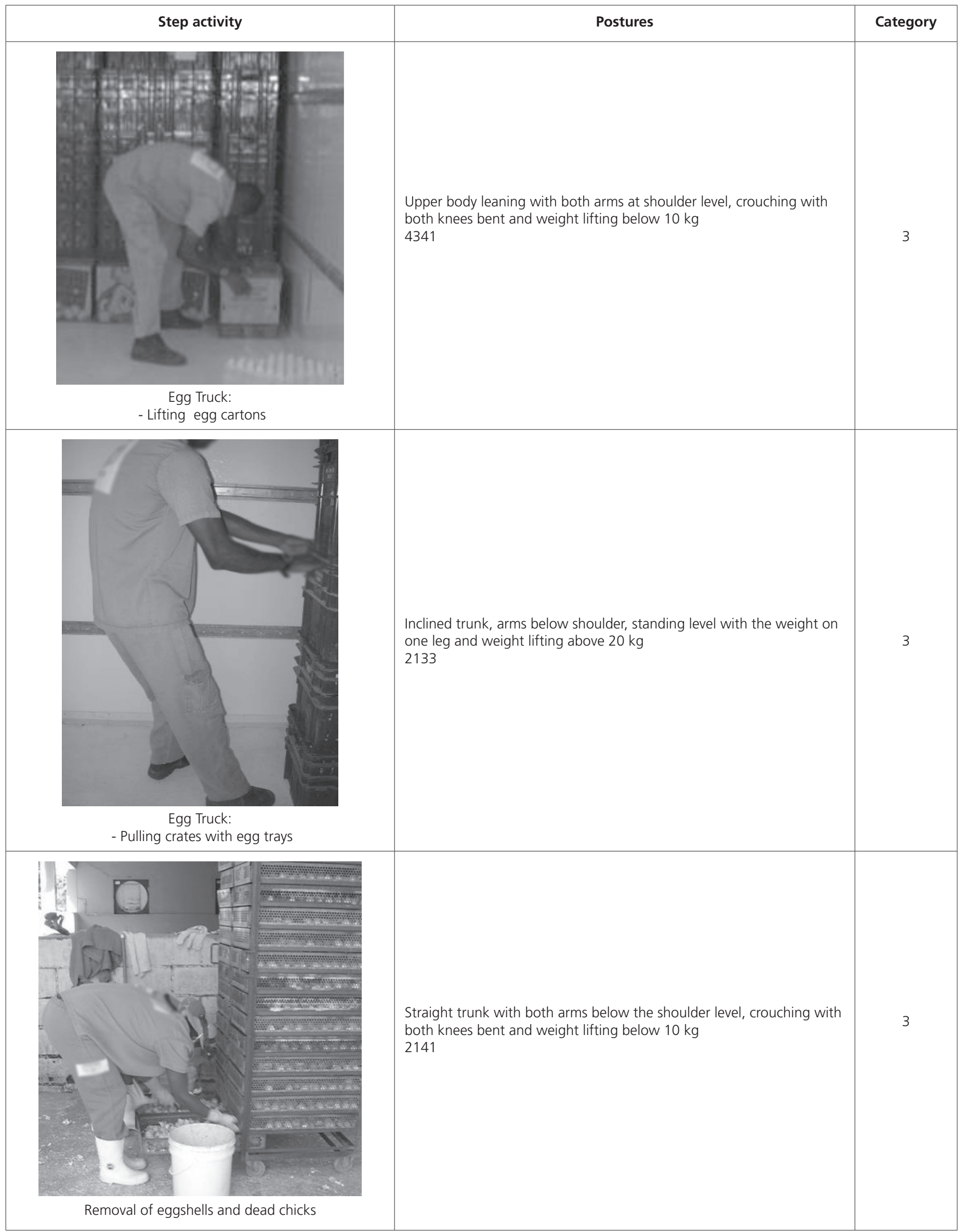




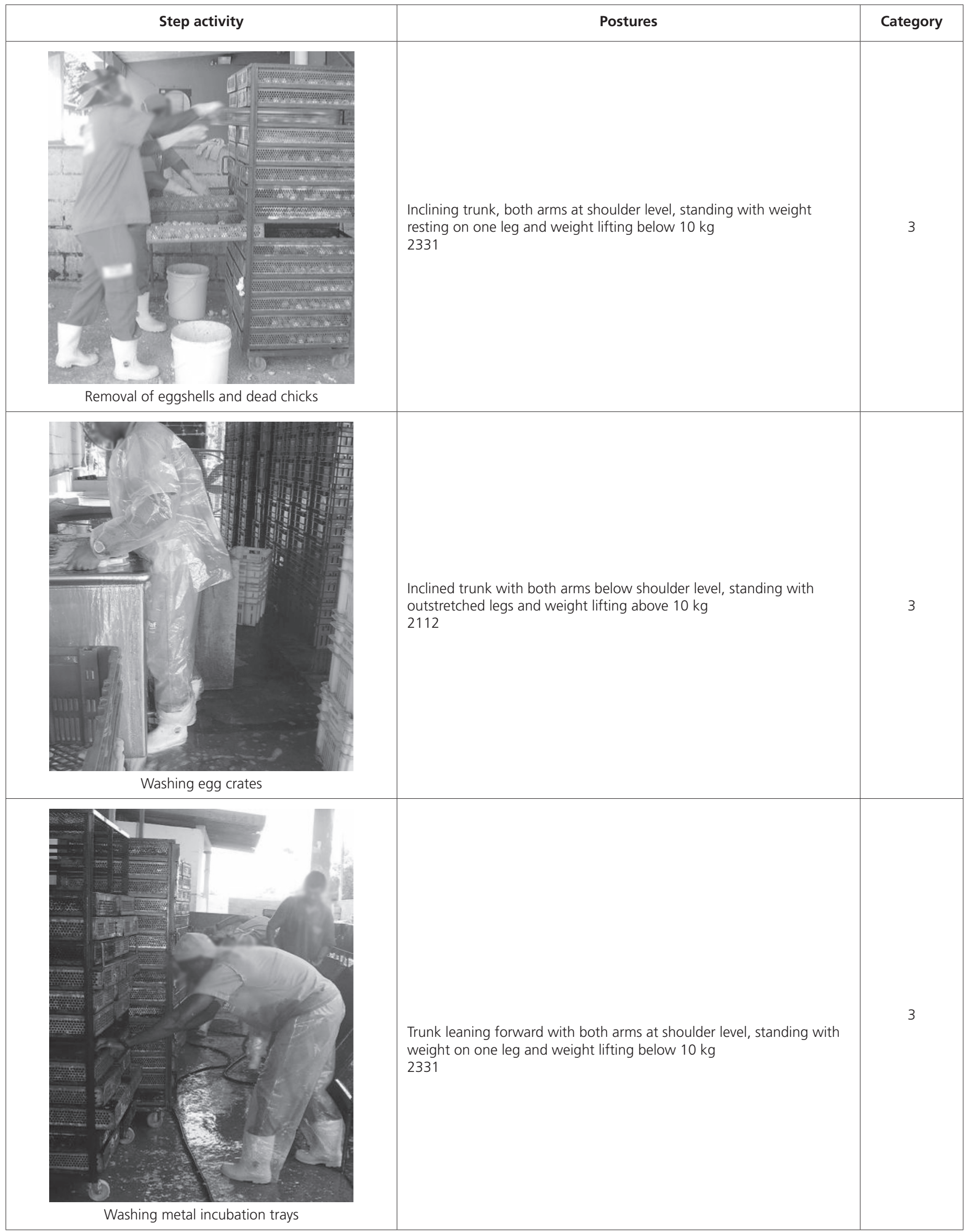




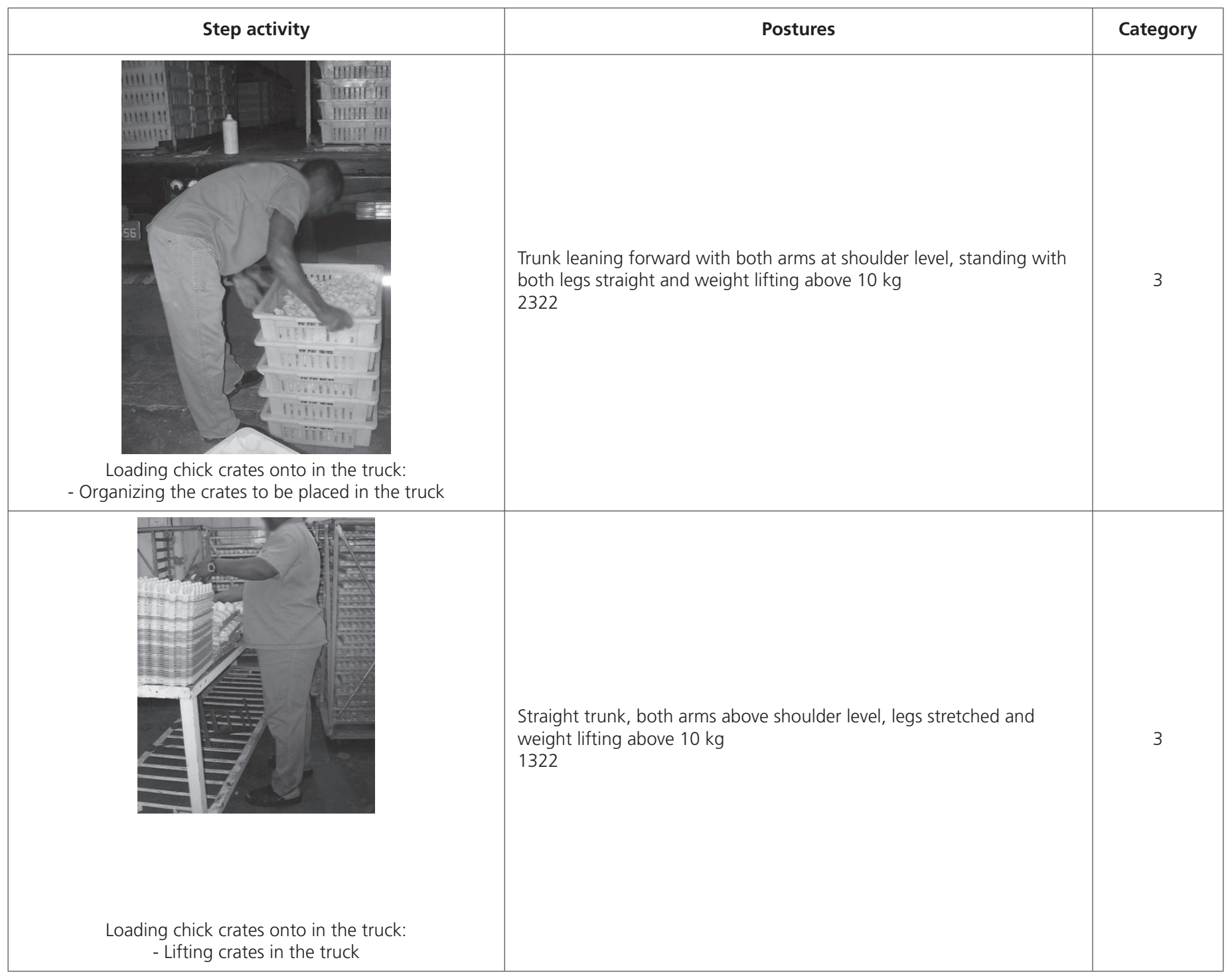

The posture assumed by employees for egg and chick grading, sexing, and vaccination was classified as category 1 and therefore, was considered normal and requiring no special care. Postures assumed during the lifting of empty egg crates, moving chick crates arriving from sexing to vaccination, the removal of eggshells and dead birds with the box at the height of the chest, and cleaning the rooms, were classified as category 2 , requiring only long-term verification.

Activities classified in category 3, where posture deserves short-term verification, were observed during pulling and lifting the egg crates, squatting to pick up chick crates, removing eggshells and dead birds when the crate was on the ground or at the top of the cart, washing plastic crates used for chick grading and metal incubator trays, as well as loading chick crates on the truck.

Activities that require workers to assume poor postures, improper handling, and excessive weight lifting may the degeneration of articular discs. The lumbar spine usually suffers the most as it supports the torso, increasing the incidence of pain (Rio \& Pires, 2001).

In order to alleviate the problems caused poor posture while performing specific activities, programs to train workers to adopt the correct posture when lifting, carrying, or pulling objects need to be developed.

Table 5 shows the postures that more frequently result in the development of joint damage for each activity, according to forced applied on the joints. The acronym RIJ indicates "No Risk of Injury in Joints", where more than $99 \%$ of workers can support the load imposed by the activity without risk to the joints involved, and RLLE indicates "Recommended Load Limit Exceeded", where less 99\% of workers can support the load imposed by the activity without risk to the joints involved. Joints in the figures as numbered as: $1=$ shoulder, $2=$ elbow, $3=$ L5/S1 disc (hip), $4=$ hip, $5=$ knee, $6=$ ankle. 
Table 5 - Summary of the biomechanical analysis of the activities performed in the hatchery

\begin{tabular}{|c|c|c|c|c|c|c|c|c|}
\hline \multirow{2}{*}{ Activity } & \multirow{2}{*}{ Phase of operation } & \multirow{2}{*}{$\begin{array}{l}\text { Static posture selected } \\
\text { for analysis }\end{array}$} & \multicolumn{6}{|c|}{ Joints and their position to bear the burden } \\
\hline & & & 1 & 2 & 3 & 4 & 5 & 6 \\
\hline \multirow{3}{*}{$\begin{array}{l}\text { Operation of un } \\
\text { truck with egg } c\end{array}$} & Pulling a single carton of eggs & & RIJ & RIJ & RIJ & RIJ & RIJ & RIJ \\
\hline & & & & & & & & \\
\hline & Pulling several egg cartons & & RLLE & RLLE & RLLE & RIJ & RLLE & RLLE \\
\hline Grading eggs & Organizing egg trays & & RIJ & RIJ & RIJ & RIJ & RIJ & RIJ \\
\hline Chick grading & Removing chicks from crate & & RIJ & RIJ & RIJ & RLLE & RIJ & RIJ \\
\hline Sexing & Lifting chick crate & & RIJ & RIJ & RIJ & RIJ & RIJ & RIJ \\
\hline Vaccination & Lifting chick crates & & RIJ & RIJ & RIJ & RIJ & RIJ & RIJ \\
\hline
\end{tabular}




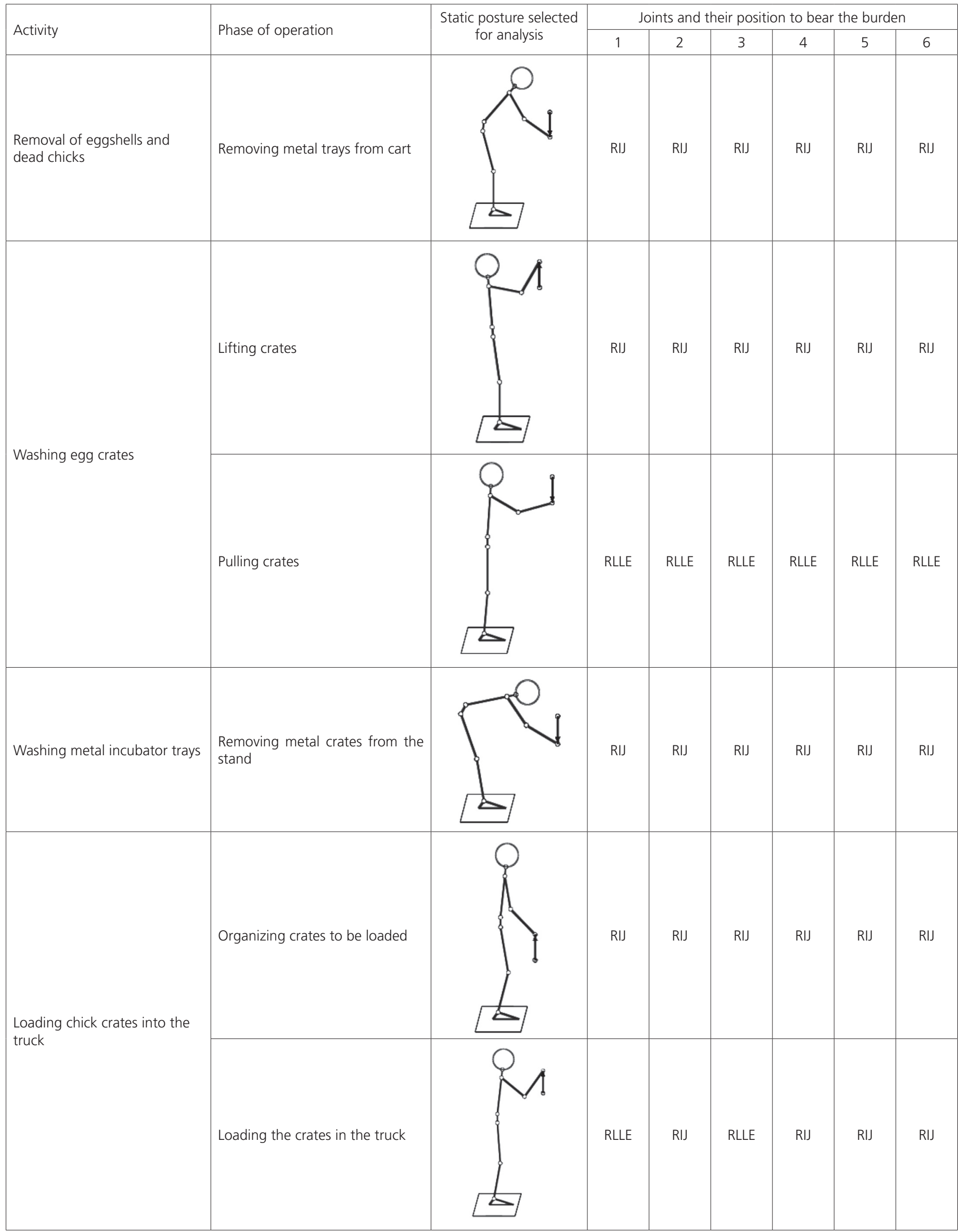


The analysis performed by the two-dimensional program indicated that, when pulling the egg crates, the workers are subject to risk of injury to the shoulder, elbow, L5/S1 disc, knee and ankle. During the washing of these crates, in addition to the risks mentioned above, there is also a risk for hip injury. This may be due not only of the weight of the crates used to store eggs, but also the postures adopted by the employees while performing these tasks.

During loading of the chick crates onto the truck, workers are exposed to risk of injury to the shoulder and L5/S1 disc due to disc herniation and the thinning of the bones and cartilages that make up this structure. These crates are stacked, forming a set of three or fourth crates that are loaded together into the truck. Back pain was reported by these employees.

It was also verified that some activities may trigger a disorder in the L5/S1 segment. According to Bostrand et al. (1989), if the compressive strength is equal to or greater than 3,423 Newtons (N), the workers may suffer severe damage to the musculoskeletal system, including rupture of the intervertebral disc. Therefore, it is necessary to reduce exposure time to this activity and load weight.

During the egg carton unloading from the truck, egg-carton weight exerts a compressive load of 3,225N on the L5/S1 disk of the worker. While removing and washing of the metal incubator trays, the compression force is $2,790 \mathrm{~N}$. The load of carrying chick crates for vaccination is $1,593 \mathrm{~N}$, while loading chick crates onto the truck which will transport them to the farms, the weight of the material generates a load of $2,153 \mathrm{~N}$ on the $\mathrm{L} 5 / \mathrm{S} 1$ disk.

\section{CONCLUSION}

In this study, it was observed that the workers of a broiler hatchery may be exposed to unhealthy working conditions, and some activities associated with weight and poor posture can result in body injury. However, meeting the safety standards, adoption of scheduled breaks, workplace gymnastics, facility improvements, use of personal protective equipment, and training employees on how to properly perform tasks may significantly contribute to reduce injuries and to improve the quality of life of the workers, thereby increasing hatchery productivity.

\section{ACKNOWLEDGEMENTS}

To the Foundation for Research Support of the State of Minas Gerais (FAPEMIG), CAPES (Coordination of
Improvement of Higher Education Personnel), CNPq (National Council for Scientific and Technological Development) and the Federal University of Viçosa (UFV).

\section{REFERENCES}

ABNT - Associação Brasileira de Normas Técnicas. Técnicas - NBR 5413 Iluminação de Interiores, 1992 [cited 2007 Jun 8]. Available from: aprender.unb.br/file.php/765/modulo_4/ecotect/NBR5413.pdf.

Bostrand L, Mobbs, ID, Strehlke B. Guidelines on ergonomic study in forestry. Genebra: ILO; 1989. 241 p.

Brasil. Portaria 3214, de 8 de junho de 1978. Aprova as Normas Regulamentadoras - NR - do capítulo V, título II, da consolidação das leis do trabalho, relativas a segurança e medicina do trabalho. Brasília: Ministério do Trabalho; 1978.

Carvalho CCS, Borém FM, Rabelo GF. Levantamento dos riscos existentes à segurança e à saúde do trabalhador na pós-colheita de café (Coffea arabica) conforme as exigências das normas regulamentadoras. Ciência e Agrotecnologia 2008;32:463-468.

Couto HA. Ergonomia aplicada ao trabalho: manual técnico da máquina humana. Belo Horizonte: ERGO Editora; 1996. v.2

Fiedler NC, Venturoli F. Avaliação da carga física de trabalho exigida em atividades de fabricação de móveis no distrito federal. Revista Cerne 2002;8(2):116-122.

Grandjean E. Manual de ergonomia: adaptando o trabalho do homem Porto Alegre: Bookman; 1998.

lida I. Ergonomia: projeto e produção. São Paulo: Edgard Blucher; 2005.

Marcon, C. L. Análise das condições de trabalho em um incubatório de aves: o caso do setor de sexagem [dissertação]. Florianópolis (SC): Universidade Federal de Santa Catarina; 2004.

Menegali I, Baeta FC, Tinoco IFF, Cordeiro MB. Guimarães MCC. Desempenho produtivo de frangos de corte em diferentes sistemas de instalações semiclimatizadas no sul do Brasil. Engenharia na Agricultura 2010;18:461-471

Rio RP, Pires L. Ergonomia: fundamentos da prática ergonômica. São Paulo: LTR; 2001. 225p.

Sacco ICN, Melo MCS, Rojas GB, Naki IK, Burgi K, Silveira LTY, et al. Análise biomecânica e cinesiológica de posturas mediante fotografia digital: estudo de casos. Revista Brasileira de Ciência e Movimento 2003:11(2):25-33.

Silva EP, Cotta RMM, Souza, AP de, Minette LU, Vieira HANF. Diagnóstico das condições de saúde de trabalhadores envolvidos na atividade em extração manual de madeira. Revista Árvore 2010; 34:561-566.

Tessari ENC, Cardoso ALSP, Castro AGM, Kanashiro AMI, Zanatta GF. Avaliação das condições sanitárias de incubatório de pintos de corte. Arquivos do Instituto Biológico 2002;69(3):1-4.

Tinoco IFF. Avicultura industrial: novos conceitos de materiais, concepções e técnicas construtivas disponíveis para galpões avícolas brasileiros. Revista Brasileira de Ciências Avícolas 2001; 3(1) [cited 2007 Jan 8]. Available from: http://www.scielo.br/scielo.php?script=sci_arttext\&pid $=$ S1516635X2001000100001\&lng=pt\&nrm=iso.

Wilson J, Corlett N. Evaluation of human work: a practical ergonomics methodology. London: Taylor \& Francis; 1995. 1119 p. 